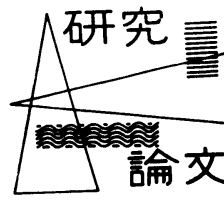

\title{
ボイラ火炉内の伝熱シミュレーション に関する研究*
}

\section{谷口 博**. 工藤一彦**. 早坂洋史 ${ }^{* * *}$}

Heat Transfer Simulation in Boiler Furnace

By Hiroshi Taniguchi, Kazuhiko Kudo, Hiroshi Hayasaka

Heat transfer simulation method in boiler furnace was developed to obtain temperature distribution and heat absorbing rate distribution in the furnace. The results were compared with experimental data from a small boiler for heavy oil. The method analyzes simultaneously the three dimensional viscous flow by vector potential method, combustive heat generating rate by a flame model with Wiebe's function, three dimensional radiative heat transfer by Monte Carlo method, and convective heat transfer and enthalpy transport due to the flow by finite difference method. Following results were obtained by this simulation.

(1) The effects on in-furnace heat transfer of the flow pattern are rather small compared with the effects of the heat generating rate distribution.

(2) Heat generating rate in boiler furnaces were made possible to be estimated by determining the Wiebe's function's parameters in the flame model by comparing the analytical results with the experimental one's.

(3) Relationship among the heat generating rate and the fuel flow rate and the air fuel ratio was investigated, and by using this, analytical results of temperature and heat absorbing rate distributions were obtained with practically sufficient degree of accuracies compared with the experimental results.

\section{1. まえがき}

舶用ボイラは陸用に比し, 従来より小形化, 高負荷化 に力が注がれてきたが, 最近の省資源, 省エネルギとい う社会動向に鑑み，従来にも増して小形かつ高効率の燃 焼技術の開発と，その設計手法の確立が重要な課題とな っている. 小形, 高効率化のためには，炉壁への熱流束 を均一化し，局所的な過熱による炻壁損傷を防止するこ とが必要であり，乙れを解析的に予測する手法の完成が 望まれていた，火炉内伝熱の解析では， 3 次元の流動解 析, この中での燃焼とこれに伴う発熱量分布の解析，及 びこの発熱量の 3 次元場での熱放射と，上記流動に伴う 熱移動による壁面への伝達の解析の三つを連成して行う 必要があるが，燃焼現象の解明が不十分なとと，火炉の 3 次元性, 及び火炎の存在による火炉内ガスの物性值変 動等のために，完全な解析は困難な状態にあった．そこ

\footnotetext{
*原稿受付 昭和 57 年 7 月 30 日

昭和 57 年春季学術講演(昭和 57 年 5 月 26 日)

**正会員 北海道大学工学部(札幌市北区北 13 条西 8 丁目)

*** 北海道大学工学部(札幌市北区北 13 条西 8 丁目)
}

で従来より各種の近似計算法が提案されてきた. 石谷 ${ }^{1)}$, 山崎 ${ }^{2)}$ は火炬を火炎部之空虚な部分とに 2 分して取扱い, 燃焼室の放射伝熱量を求めた. Hottel ら ${ }^{3)}$ は流動, 放射, 対流伝熱の解析を行ったが, 火炉内ガスの吸収係数を一 定としたため，一般的な適用は困難である.Gosman ら4) は放射伝熱を無視し，流動之対流伝熱の式を簡単な燃焼 の式と連立して 2 次元場でしれを解析した. 燃焼が連成 されている点で評価できるが，放射伝熱を無視している ため実用上問題がある. これらに対し，我々は火炬解析 において燃焼解析についでやっかいな 3 次元不均質場で の放射伝熱解析にモンテカルロ法を導入し, 流動及び対 流伝熱との連成を容易にした ${ }^{5,6)}$. この解析では，流動 として簡単のために均一ピストン流れを仮定し，また発 熱量分布は所与の火炎形状の中で均一であるとした.

本報ではまず然焼による発熱量分布の解析を除く他の 部分の解析を，できるだけ実際の火炉内の現象に近付け るため, 流動として新たに 3 次元の粘性流動解析を上記 解析に導入し，てれを用いて各種燃焼条件での実験デー 夕との比較より, 逆に火炎内での発熱量分布を推定した. これは，発熱量分布を解析的あるいは実験的に求めるこ 
とが困難であるため，てのようにして求めた発熱量分布 とそれに対応した燃焼条件との関係を調へ，発熱量分布 の定式化を試みたあのである．本報では，所与の火炎形 状中にての式より算出される発熱量分布を入れ，上記解 析法により求めた火炉内温度分布，火炉壁面受熱量分布 を実験結果と比較し，各種の燃焼条件に対し良い一致を 得ることができた。

\section{2. 実験装置及び実験方法}

3 次元火炉の解析モデルの対象としては, 図 1 亿示す 小形重油だきボイラを選定した．仕様を表 1 に示す. 図 中の(1)〜6)の番号は壁面番号である. (5)番壁面のほぼ中 央のバーナ部より燃料と空気が流入し，火炉内で輝炎を 形成し，燃焼後の排ガスは(2)番壁面の後部よりボイラ接 触伝熱面の管群部に流入し, 煙突加ら排出される. 火炉 内の温度分布は，図1の6番壁面に設けた温度测定孔 $\mathrm{T}$ から吸引温度計を挿入して测定した。 また火炉壁面の受 熱量分布は，(1)番壁面にある测定孔 $\mathrm{a} \sim \mathrm{h}$ に熱流計を装 着して测定した，実験は，表 2 に示す範囲で重油燃焼量 と空気過剰係数を変化させるとともに，バーナ噴霧角を

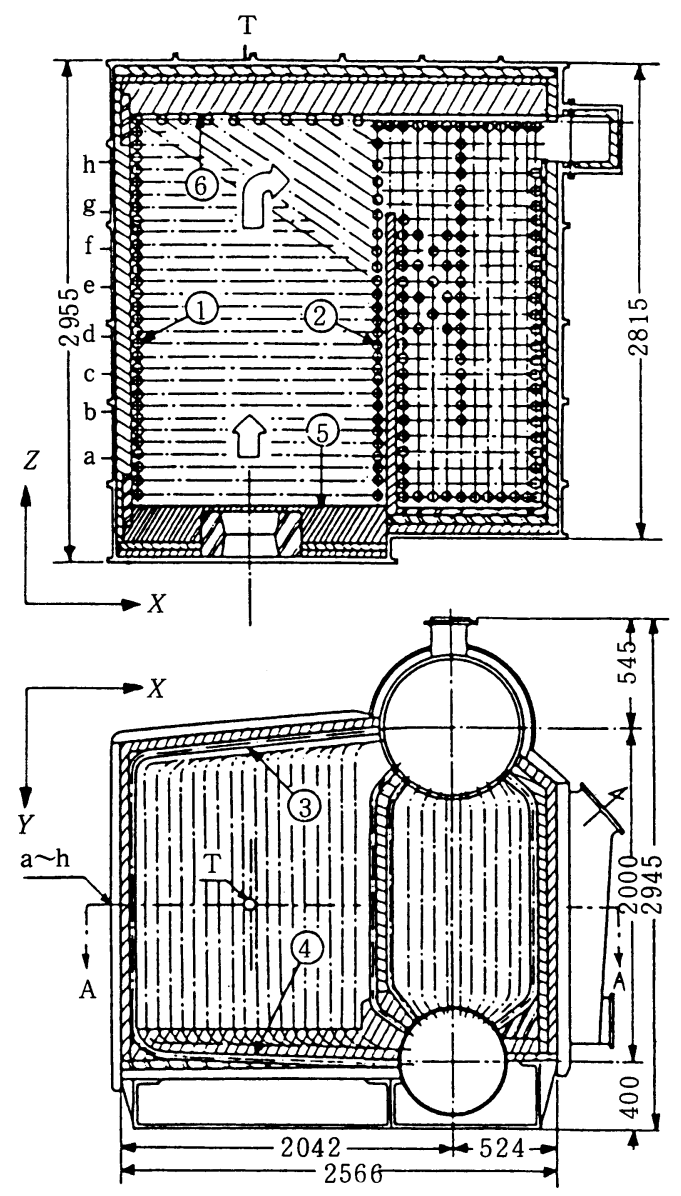

図 1 ボイラ概略図
変えて, 火炉内の熱伝達に大きな影響を及ぼす火炎の形 状を変化させた。燃焼はほぼ完全燃焼条件で行った。計 算に用いる条件を表 3 に示す. 火炎吸収係数は解析上重 要な值であるが，その分布の正確な測定は困難であるの で, 放射温度計及び吸引温度計による火炎温度の测定結 果加ら平均吸収係数を算出した. この值は火炉内の燃焼 条件により変化するが，0.5〜1 まで変化させた解析にお いて炉内温度分布に大きな差異が生じないことを確認の 上で表 3 の值に固定した. 燃焼ガスの吸収係数は， $\mathrm{CO}_{2}$ と $\mathrm{H}_{2} \mathrm{O}$ の放射率より算出した. また壁面温度は，水冷壁 については蒸気圧力に対応した飽和温度を，また(4)(5の

表 1 ボイラ仕様

\begin{tabular}{|c|c|c|}
\hline ボイラ形式 & \multicolumn{2}{|c|}{2 胴曲管水管ボイラ } \\
\hline \multirow{2}{*}{ 蒸 発 量 } & 最大連続負荷 & \multirow{2}{*}{$\begin{array}{l}2000 \mathrm{~kg} / \mathrm{h} \\
1500 \mathrm{~kg} / \mathrm{h}\end{array}$} \\
\hline & 経 斉 負 荷 & \\
\hline \multirow{2}{*}{ 蒸 気 圧 } & 最 高 使 用 & \multirow{2}{*}{$\begin{array}{l}14 \mathrm{~kg} / \mathrm{cm}^{2} \cdot \mathrm{g} \\
10 \mathrm{~kg} / \mathrm{cm}^{2} \cdot \mathrm{g}\end{array}$} \\
\hline & 用 & \\
\hline 蒸 & 度 & 飽 \\
\hline \multirow{3}{*}{ 伝熱面 積 } & ボイラ本体 & $53.6 \mathrm{~m}^{2}$ \\
\hline & 水冷 火 炬 & $32.1 \mathrm{~m}^{2}$ \\
\hline & 計 & $85.7 \mathrm{~m}^{2}$ \\
\hline 火 & 積 & $5.9 \mathrm{~m}^{3}$ \\
\hline \multicolumn{2}{|c|}{ か ん（午） 水 容 積 } & 約 $3.5 \mathrm{t}$ \\
\hline \multicolumn{2}{|c|}{ 火炉最大連 続 負 荷 } & $259000 \mathrm{kcal} / \mathrm{m}^{3} \cdot \mathrm{h}$ \\
\hline \multicolumn{2}{|c|}{ 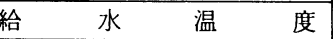 } & $20^{C} \mathrm{C}$ \\
\hline \multicolumn{2}{|l|}{ 空 } & $20^{\circ} \mathrm{C}$ \\
\hline \multicolumn{2}{|l|}{ 通 } & 強 圧 通 風 \\
\hline \multicolumn{2}{|l|}{ 燃 } & 重 油 専 焼 \\
\hline \multicolumn{2}{|c|}{ 燃 料 低 発 熱 量 } & $10810 \mathrm{kcal} / \mathrm{kg}$ \\
\hline
\end{tabular}

\section{表 2 実験条件}

\begin{tabular}{|c|c|c|c|c|}
\hline $\begin{array}{l}\text { 実験 } \\
\text { 番号 }\end{array}$ & $\begin{array}{c}\text { 燃焼量 } \\
G_{\mathrm{f}}(\mathrm{l} / \mathrm{h}) \\
\end{array}$ & $\begin{array}{c}\text { 火炎長さ } \\
L_{\mathrm{f}}(\mathrm{m}) \\
\end{array}$ & $\begin{array}{c}\text { 空気過剩係数 } \\
(\phi)\end{array}$ & $\begin{array}{c}\text { バーナ噴霧角 } \\
(\boldsymbol{\beta})\end{array}$ \\
\hline 531 & 100 & 1.46 & \multirow{5}{*}{1.1} & \multirow{7}{*}{$70^{\circ}$} \\
\hline 532 & 120 & 1.76 & & \\
\hline 533 & 150 & 2.05 & & \\
\hline 535 & 200 & 2.34 & & \\
\hline 541 & \multirow{4}{*}{150} & 2.34 & & \\
\hline 542 & & 1.76 & 1.32 & \\
\hline 543 & & 1.17 & 1.61 & \\
\hline 552 & & 2.34 & 1.26 & $50^{\circ}$ \\
\hline
\end{tabular}

\section{表 3 計算条件}

\begin{tabular}{|l|l|c|}
\hline \multirow{2}{*}{ 放射吸収係数 } & 火 炎 & $0.77 \mathrm{~m}^{-1}$ \\
\cline { 2 - 3 } & 燃焼ガ ス & $0.21 \mathrm{~m}^{-1}$ \\
\hline 火炉壁対流熱伝達率 & $14.0 \mathrm{kcal} /\left(\mathrm{m}^{2} \cdot \mathrm{h} \cdot \mathrm{C}\right)$ \\
\hline 燃焼ガスの定圧比熱 & $0.27 \mathrm{kcal} /(\mathrm{kg} \cdot \mathrm{C})$ \\
\hline
\end{tabular}

\begin{tabular}{|l|c|c|c|c|c|c|}
\hline 壁 面 番 号 & (1) & (2) & (3) & (4) & (5) & (6) \\
\hline 壁 面 放 射 率 & 1.0 & 0.9 & 1.0 & 0 & 0 & 0.8 \\
\hline 壁面温度 (C) & 182 & 182 & 182 & 657 & 707 & 182 \\
\hline
\end{tabular}


壁面については熱電対の実測值を使用した.

\section{3. 解析方法}

解析に当っては図 1 の火炉部分を高さ $1,500 \mathrm{~mm}$ ，横幅 $1,835 \mathrm{~mm}$, 奥行き $2,340 \mathrm{~mm}$ の直方体之考え，流動，燃 焼及び伝熱の解析を行った。

\section{1 流動解析 火炉内伝熱に打矿流動の影響を} 調べるため, 均一ピストン流れ，2 次元ポテンシャル流 れ，及び 3 次元粘性流れの 3 種類の流動について解析を 行った. 2 次元ポテンシャル流れについては， $X-Z$ 平 面上の 2 次元条件とし，バーナ断面より均一に流入し， 炬出口より均一に流出する条件で，緩和法により流れ関 数を計算し質量速度を求めた. 3 次元粘性流れは, ベク トルポテンシャル7) 導入し，同時反復法を用いて質量 速度を求めた。解法としては， 3 次元のナビエ・ストー クスの方程式と連続の式を式(1) で定義されるべクトル 渦度を用いて結合した，下記の定常状態に抢ける渦度移 動方程式を用いる.

$$
\begin{aligned}
& \vec{\zeta}=\nabla \times \vec{v} \\
& -\nabla \cdot\left(\rho \vec{v} \zeta_{x}\right)+\mu_{\text {eff }} \nabla^{2}\left(\rho \zeta_{x}\right)+\vec{\zeta} \cdot \nabla(\rho u)=0 \\
& -\nabla \cdot\left(\rho \vec{v} \zeta_{y}\right)+\mu_{\text {eff }} \nabla^{2}\left(\rho \zeta_{y}\right)+\vec{\zeta} \cdot \nabla(\rho v)=0 \\
& -\nabla \cdot\left(\rho \vec{v} \zeta_{z}\right)+\mu_{\text {eff }} \nabla^{2}\left(\rho \zeta_{z}\right)+\vec{\zeta} \cdot \nabla(\rho w)=0
\end{aligned}
$$

ここで は密度， $u, v, w$ は各々 $x, y, z$ 方向の線速度， 度， $\mu_{\text {eff }}$ は実効粘性係数である. 次にこの場合に流れ関 数 $\phi$ を考えると， $\phi$ は一組の 3 次元流れに対してそのま までは存在せず, 流速が $\nabla \times \vec{\phi}$ から求められるべクトル ポテンシャル $\vec{\phi}=\phi_{x} \vec{i}+\phi_{y} \vec{j}+\phi_{z} \vec{k}$ を考えるとととなる. とてで

$$
\vec{v}=\nabla \times \vec{\phi}
$$

である. 式(1)，(5)より次式が得られる.

$$
\nabla^{2} \vec{\phi}=-\vec{\zeta}
$$

以上により火炉内の 3 次元粘性流れを解いた.

3.2 燃焼解析 ボイラ等火炉内の燃焼反応につい ては, 流動が複雑であり測定も困難であることから，厳 密な燃焼解析が行われた例は無く，各種のモデルが提案 されているものの, 乱れ之燃焼反応の関係等が必ずしも 明確でない. 本研究ではこのため, 図 2 (a) の火炎形状 之, 式 (7) のWiebe の燃え切り関数 ${ }^{8}$ による $z$ 軸方向の 発熱量分布を与え。炉内の燃焼発熱を模擬することと した．主な仮定は以下のと打りである。

（1）燃焼室内を発熱ジーン(火炎) と非発熱ゾーン(燃 赎ガス)の二つに分離する.

（2）両ゾーン境界の火炎形状は図 2 (a) の形状とし, 長さを実験時の観察により(表 $2 L_{\mathrm{f}}$ 参照)，またその開 き角度はバーナの噴霧角度 $(\beta)$ 加ら決定する.

（3）バーナの軸江直角な平面上での発熱量分布は一様 とし， $z$ 軸方向に次式で定義される発熱量分布を有する あのとする ${ }^{8}$.

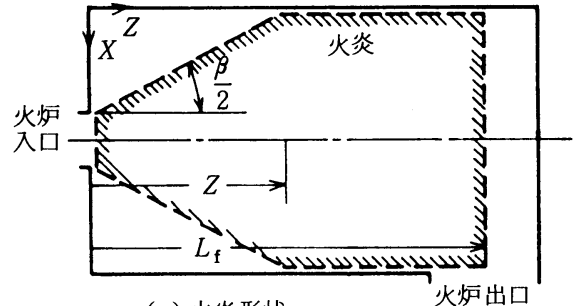

(a) 火炎形状

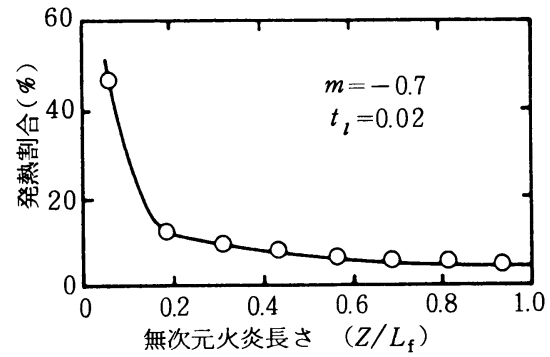

(b) 発熱割合

図 2 火炎モデル

$$
H_{z}=1-\exp \left\{-6.9\left(t_{l} \cdot \frac{t}{t_{z}}\right)^{m+1}\right\}
$$

ここで $H_{z}$ は火炬 $z$ 方向の燃料の燃焼した割合， $t$ は時間， $t_{l}, m$ は指数， $t_{z}$ は燃焼時間である. $t_{z}$ は火炎長さをバ 一ナ軸線上の平均ガス流速で除して求めた. 式 (7) は指 数の調節により内燃機関, ガスタービン等の内部での燃 焼を良く表現できる半実験式であることが知られている。

\section{3 伝熱解析炬内の伝熱解析は, 放射伝熱に} 関してはモンテカルロ法を，また対流伝熱及び流動によ る熱移動に関しては差分法を用いて行った. 火炬内ガス は，火炎，燃焼ガス共灰色ガスとして取扱った。また炉 壁は表 3 に示すような温度及び放射率を有する灰色体と して取扱った. 火炉内小体積のガスに抢けるエネルギ方 程式は次式であらわされる.

$$
\begin{aligned}
4 K E_{\mathbf{g}}= & \int_{V} 4 K E_{\mathrm{g}} R_{\mathrm{sg}} d V+\int_{A} \varepsilon_{\mathrm{w}} E_{\mathbf{w}} R_{\mathrm{sw}} d A+Q \\
& -\rho C_{p}\left(u \frac{\partial T_{\mathbf{g}}}{\partial x}+v \frac{\partial T_{\mathbf{g}}}{\partial y}+w \frac{\partial T_{\mathbf{g}}}{\partial z}\right)
\end{aligned}
$$

ここで $K$ は放射吸収係数， $E_{\mathrm{g}}, E_{\mathrm{w}}$ は火炉内ガスと火炉 壁の射出能で， $\sigma T_{\mathrm{g}}^{4} ， \sigma T_{\mathrm{w}}^{4}$ で表わされる. 次に $R_{\mathrm{sg}}, R_{\mathrm{sw}}$ は火炉内ガスと火炉壁部分での熱エネルギの吸収される 確率， $V$ は火炉体積， $A$ は火火炉壁面積， $\varepsilon_{\mathrm{w}}$ は火火炉壁の放 射率，Qは微小要素体積における発熱量, $○$ は燃焼ガス の密度， $C_{p}$ は燃焼ガスの定圧比熱， $u, v, w$ は各々 $x$, $y, z$ 軸方向の線速度， $T_{\mathrm{g}}$ は火火炉内ガス温度である. ま た，火炉壁面の小区分でのエネルギ方程式は次式で表わ される。

$$
\begin{aligned}
h_{\mathrm{w}}= & \int_{V} 4 K E_{\mathrm{g}} R_{\mathrm{sg}} d V+\int_{A} \varepsilon_{\mathrm{w}} E_{\mathrm{w}} R_{\mathrm{sw}} d A \\
& +\alpha\left(T_{\mathrm{g}}-T_{\mathrm{w}}\right)-\varepsilon_{\mathrm{w}} E_{\mathrm{w}}
\end{aligned}
$$

ここで $h_{\mathrm{w}}$ は火炬壁面熱吸収量, $\alpha$ は対流熱伝達率, $T_{\mathrm{w}}$ 
は火炉壁面温度である. 式 (8)，(9)を解くことにより, 火炉内の温度分布と火炉壁面の熱吸収量分布を求めるこ とができる. 具体的には，火炉内の温度分布を仮定し， これにもとづき各小体積及び壁面の小区分より射出すべ き放射エネルギを決定する．次にてれに比例した本数の 放射エネルギ束を考え，乙れの射出方向と，小体積ある いは小区分内での射出位置及び吸収されるまでに走る距 離を乱数で決定する. 射出したエネルギ束が壁に当った ときは，壁面の放射率で決定される確率で反射加吸収か を決定する. このようにして全エネルギ束の射出，吸収 の追跡が終了したら，各小体積，小区分で吸収したエネ ルギ束を加え合わせるととにより，放射受熱量が決定さ れる. これを対流伝熱量, 流動による熱移動量, 及び発 熱量が各小体積で平衡に達するように最初の温度分布の 仮定を繰返し修正するととにより，必要な炉内の温度分 布を求めることができる．また，収束時の壁面における 熱収支の差が，壁面における熱吸収量となる.

\section{4. 解析結果}

4.1 火炉内発熱量分布 前章の解析モデルに式 （7）のWiebeの燃え切り関数を代入して火炬内温度分布 之壁面受熱量分布を算出し, 测定結果との比較より同式 の指数 $m, t_{l}$ の適正值，すなわち実験時の発熱量分布を 推定した. 図 3 にWiebe の関数の $m$ 之 $t_{l}$ に対する挙動 を示す. この図より $m$ を一定にして $t_{l}$ を減少させると火 炉入口部での発熱割合が減少して下流部で増加するとと が，また $t_{l}$ を一定にして $m$ を大きくすると火炉入口部で の発熱割合が急減し，発熱量最大のピークが下流側にず れることが分かる。な掺考のため，乙れらの発熱量分 布パターンに加え, 従来の均一な発熱量分布についても 合わせて検討した.

図 4,5 に $t_{l}$ が一定の場合の, また図 6,7 に $m$ が一定 の場合の火炬内中心軸上温度分布之火炉壁面受熱量分布 の計算結果と測定結果の比較を示した. 図 4,5 より $m$

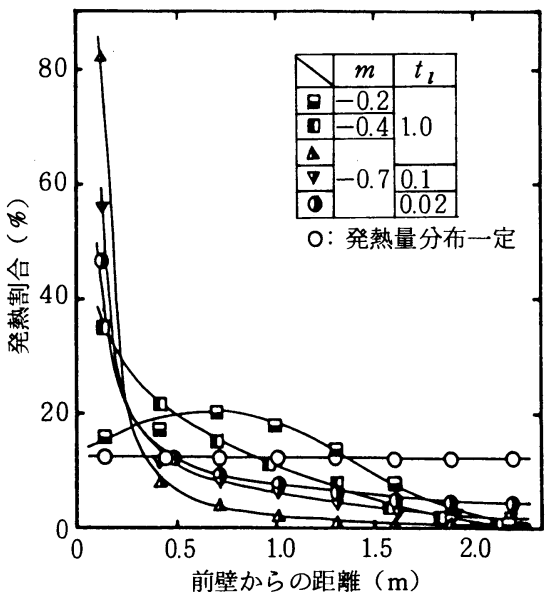

図 3 発熱量分布

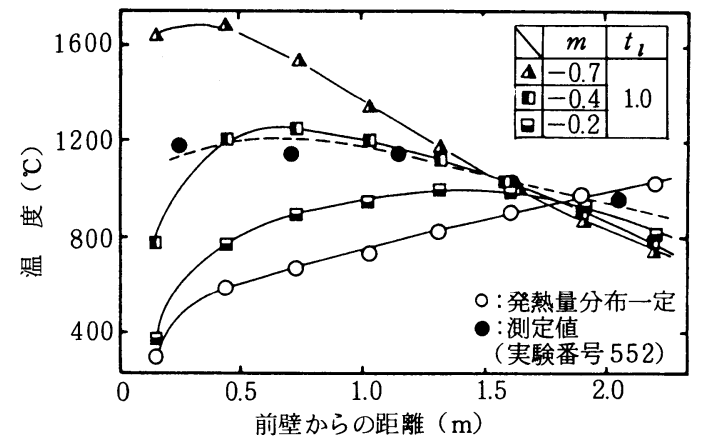

図4 温度分布への影響(1)

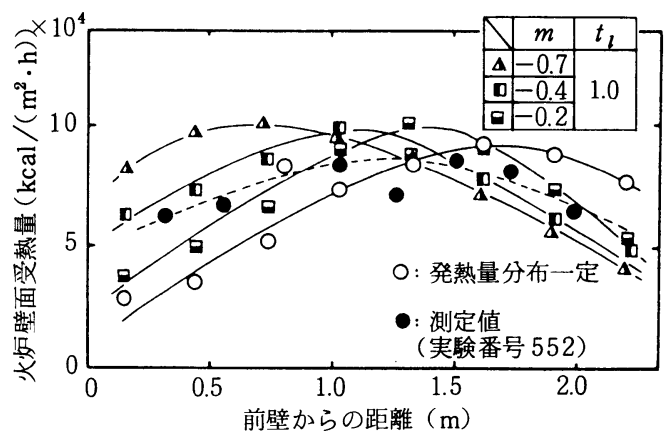

図 5 受熱量分布への影響 (1)

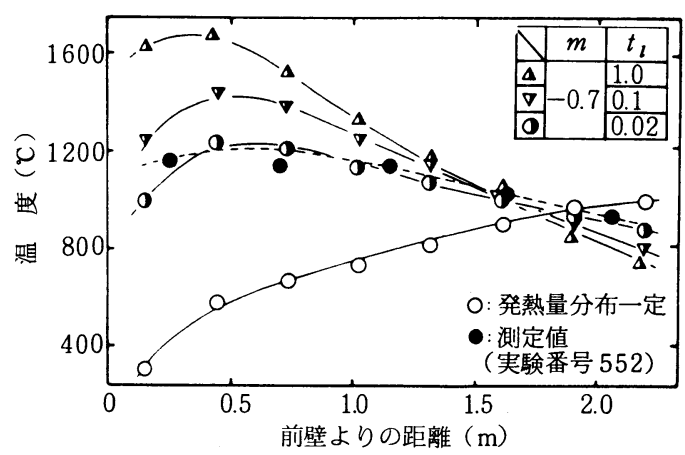

図 6 温度分布への影響 (2)

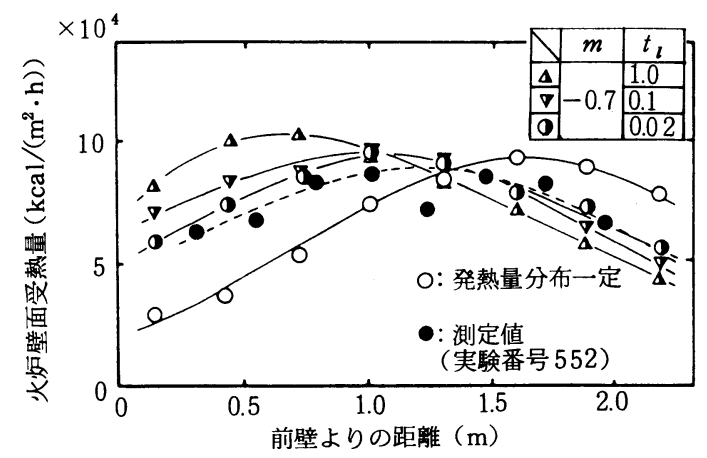

図 7 受熱量分布への影響 (2) 
を小さくして火炉入口での発熱割合を増加させると，乙 の部分に打りる温度が上昇し, また壁面への受熱量も增 加するてとが分かる. これは，入口部では火炎が炉内に 充満して抢らず，火炎と炉壁との間に吸収係数の小さい 燃焼ガスが存在しているため, 中心軸上の温度上昇が直 接壁面の受熱量增加に結びついたと考えられる. これに 対し，入口部から $1.5 \mathrm{~m}$ 位下流に行ったところでは，中 心軸上の温度が等しいにもかかわらず，mの大きい方が 壁面受熱量が大きいととが示されている．乙れは，この 部分では吸収係数の大きい火炎が火炉内に充満していた ため，中心軸上よりむしろ壁面近傍の火炎温度が壁面受 熱量に効いてくるためである.すなわち （入口付近で発熱量にピークがある場合）には，中心軸上 ではこの熱量が流動により下流に移動されて比較的高温 を保つのに対し，壁面近傍では上流から熱量があまり流 入せずまた対象領域付近では入口付近の発熱量のピーク からはなれているため発熱量が少なく，乙のために温度 が中心軸上に比してかなり低くなっている．てれに対し mの大きい場合には, 中流で発熱量にピークがあるので, 対象領域付近での発熱量が大きく，てのため中心軸上と 壁面付近との温度差が少ない，したがって壁面付近の火 炎温度は $m$ 大の方が高くなっており，乙れが図 5 の中流 部で $m$ 大の方が受熱量が多くなっている理由である. 図 4,5 で $t_{l}=1.0$ 一定とした場合, $m=-0.4$ で温度分布が 実測值之合致するが，受熱量分布に差が生じる. これに 対し, 図 6, 7 で $m=-0.7$ 一定と扑いて $t_{l}$ を変化させた 場合, $t_{l}=0.02$ で温度分布, 発熱量分布とも比較的良い 一致を示すことがわかる. これから，重油燃焼において， 実験番号 552 (表 2 参照)の燃焼条件に抢いて, $m=-0.7$, $t_{l}=0.02$ とすれば啇正発熱量分布を与えることができる ことが示された.

4.2 流動様式の影響 以上により求めた発熱量 分布式を用いて，火炉内伝熱に及ぼす火炉内流動様式の 影響を検討した. 乙の場合の流動様式としては，図 8, 9,10 亿示す 3 種類の流れを対象とする. 図 8 の均一流 れの場合には，炉壁全面上り流入し，横に曲らずに直進 して炉壁全面より流出するてと，また火炎が火炉内に充 満していることなど最も単純な場合である. ポテンシャ ル流れの場合は， $X-Z$ 平面上の 2 次元条件で検討した. 乙の場合, 火炬入口から流入した流れは火炬内で急激に 広がり，均一流れとなり，その後火炉後部の出口より均 一に流出するという，比較的実際に近い流動様式である. 3 次元粘性流机の場合は，火炉中心軸上の質量速度が大 きく，火炉入口部周辺で循環域を有する流動様式となる. この流動様式は実験に抢ける火炎の広がりの観測や，燃 焼用空気の流入方式を考虑すると妥当なもの之考云る. 解析使用した実効粘性係数の值は, 火炎の広がり角及 び他の研究結果を参考にして, $0.3 \mathrm{kgf} ・ \mathrm{~s} / \mathrm{m}^{2}\{2.9 \mathrm{~Pa} ・ \mathrm{~s}\}$ とした. こてで, 火炉入口部での循環領域の大きさは， 空気過剩率，負荷等により变化する可能性があるので，

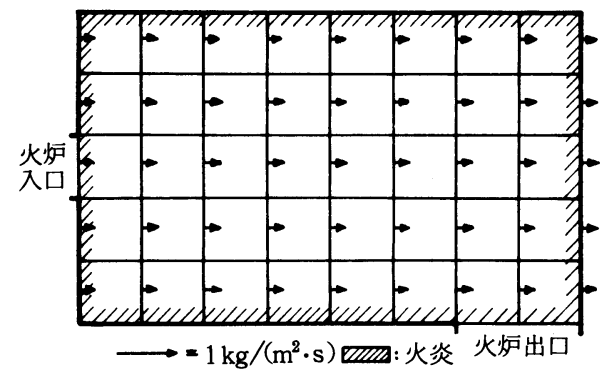

図 8 均一流れの火炉内質量速度分布

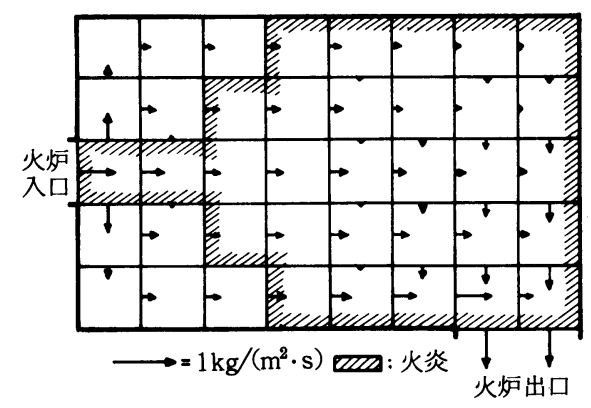

図 92 次元ポテンシャル流れの 火炉内質量速度分布

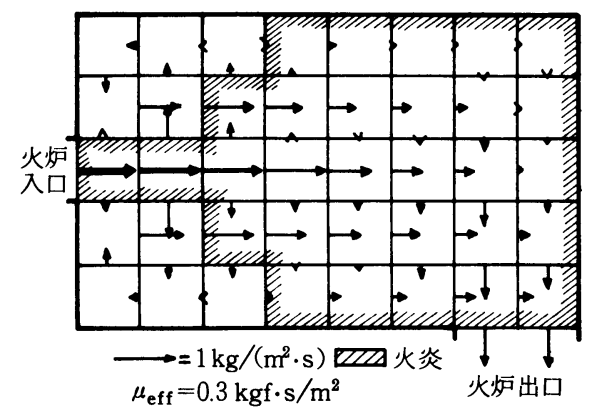

図 103 次元粘性流れの火炉内質量速度分布

3 次元粘性流れの解析では，実効粘性係数を $0.5 \mathrm{kgf} \cdot \mathrm{s} /$ $\mathrm{m}^{2}\{4.9 \mathrm{~Pa} \cdot \mathrm{s}\}$ に增加させ，循環領域を減少させた場合も 検討した. 図11,12 にてれらの流動様式に対応した火炉 中心軸上の温度分布と壁面受熱量分布を示す. 図 11,12 より 3 次元粘性流れから流れがずれるほど，測定結果か らのずれが大きくなること，また実効粘性係数の影響は あまり大きくないととが分かる．均一流れでは火炎が火 炬内に充満して流れているため, 中心軸上の発熱量が他 の流れ様式の場合に比して少なく，したがって中心軸上 の温度が低く，また壁面受熱量が高くでている．図 4 ， $5,6,7$ 之図 11,12 の比較上り火炉内の伝熱に対し, 流 動様式の差異が与える影響は, 発熱量分析のそれに比し て小さいととが分かる．したがって，今回の 3 次元の粘 性流れ解析の結果を火炬伝熱の解析に組み込むととによ り，発熱量分布が適当であれば，妥当な温度分布及び壁 面受熱量分布か得られること，逆にてのモデルを用いて 


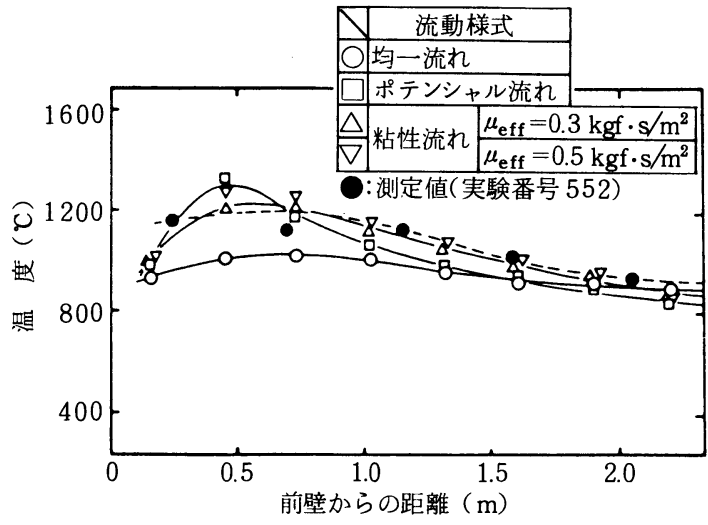

図 11 火炉中心の温度分布

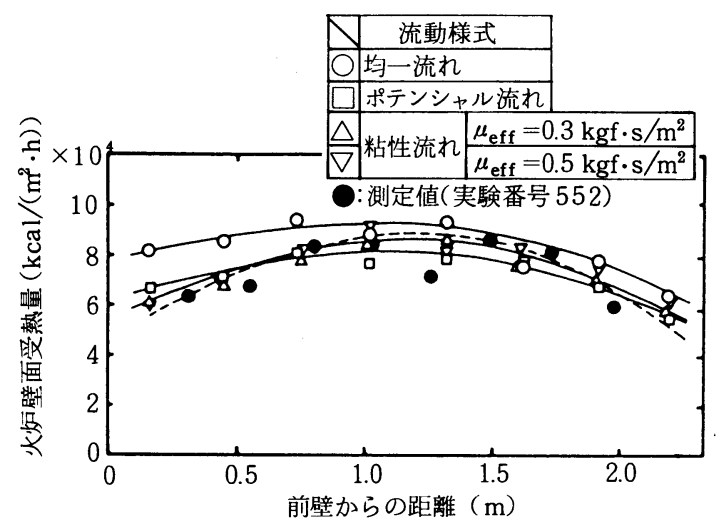

図 12 火炉壁面受熱量分布

これらの実测值より妥当な発熱量分布を逆算できること が推察される. 以下，てのようにして求められた発熱量 分布をもとに, 燃焼条件と発熱量分布との関係を調べた 結果を示す.

\section{3 燃焼条件の影響}

4.3.1 発熱量分布の推定燃焼条件として, 表 2 に示すように燃料流量 $100 \sim 200 \mathrm{l} / \mathrm{h}$, 空気過劋係数を 1.1〜 1.61 まで変化させたときの実験結果を用い, 発熱量 分布を示す式 (7) の指数の值の変化を求めた. とのよう な条件変化により，火炎長さは同表に示すように1.17〜 $2.34 \mathrm{~m}$ (火炉に充満した状態) まで変化している. この検 討では $m$ を一定とし， $t_{l}$ を変化させて各条件に対応した 発熱量分布を求めることとした. その結果, $t_{l}$ の最大值 は火炎が充満した条件に相当し, 最小值は燃焼量の最も 少ない条件に相当していることが分かった．さらにての $t_{l}$ と燃焼条件 $\left(\phi, G_{\mathrm{f}}\right)$ の関係について検討した結果, 図 13 のように $G_{\mathrm{f}} / \sqrt{\phi}$ をパラメータとして整理できるてと が分かった. この図より, 空気過㮃係数 $\phi$ が 1.1 で一定 のとき, 燃料流量 $G_{\mathrm{f}}$ を増加させると $t_{l}$ あ増加し，一定值 に近づくことが分かる. この最大值は $L_{\mathrm{f}}$ が $2.34 \mathrm{~m}$ で，火 炉内に火炎が充満した場合に相当する. 以上のことから, 炉形, バーナを定めると, 発熱量分布は燃料流量と空気

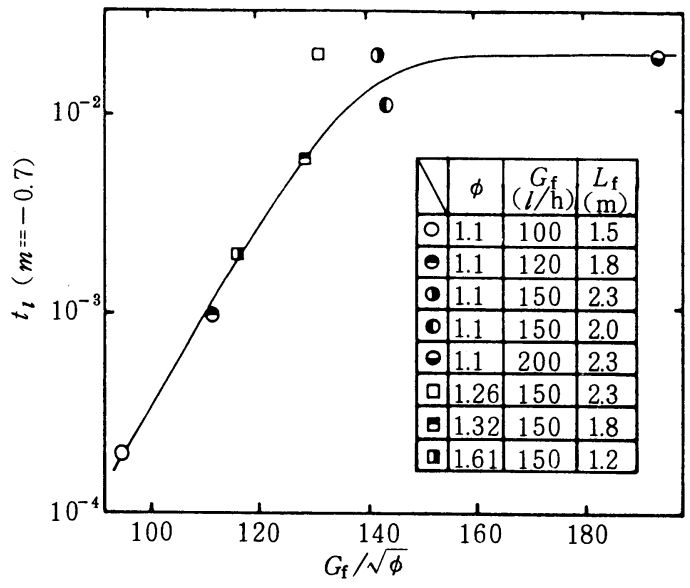

図 $13 t_{l}-G_{\mathrm{f}} / \sqrt{\phi}$ 線図

過剰係数から推定可能であることが分かった.

4.3.2 空気過剩係数の影響 図 13 の $t_{l}$ を入れて 求めた発熱量分布を用い，燃料流量 $150 \mathrm{l} / \mathrm{h}$ 一定で, 空 気過㮃係数を 1.1 から 1.61 の間で変化させた場合の，火 炉中心軸上の温度分布之火炉壁面受熱量分布の計算値之 実測值の比較を図 14,15 に示す. 図 14 より，空気過㮃 係数の増加につれ，中心軸上の温度测定值が減少する傾 向を示すことが分かる.乙れに対し，実線の計算值は，

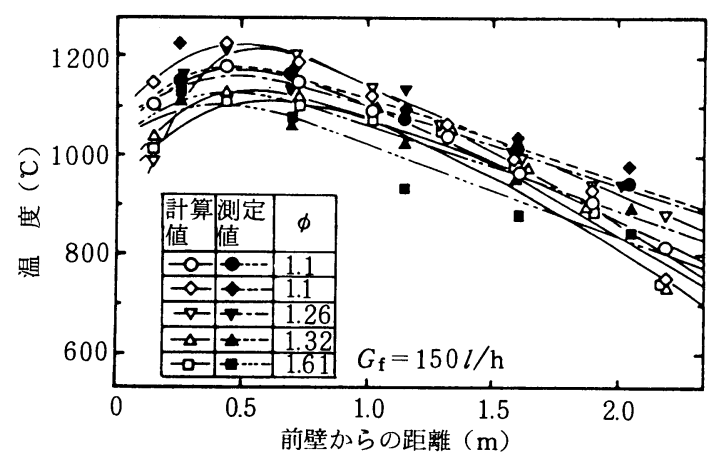

図 14 空気過剰係数の影響 (1)

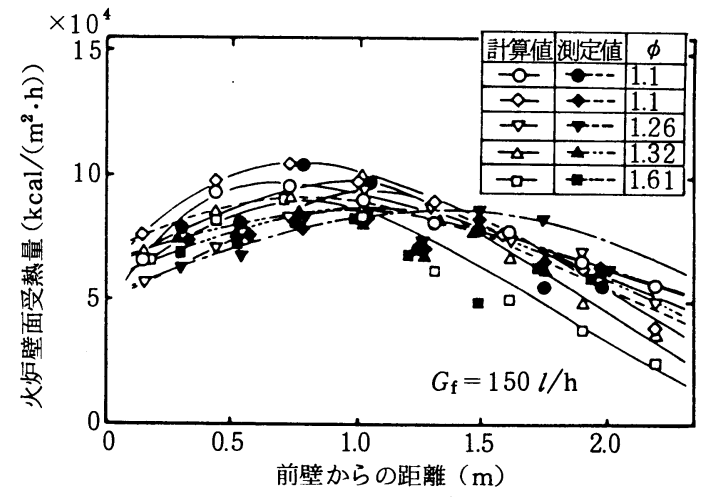

困 15 空気過剰係数の影響 (2) 
一部を除いて值及び傾向とも良く合っている. 図 15 の 受熱量分布については, 空気過剩係数の違いによる測定 值の傾向が明確でないため，はっきりしたことは言えな いが, 計算值と実験值は比較的良い一致を示しているこ とが分かる.

4.3.3 燃料流量の影響 前項之同様, 図 13 の $t_{l}$ により求めた発熱量分布を用い, 空気過剩係数 1.1 一定 で燃料流量を 100 200 l/h と変化させた場合の計算結 果と実験結果との比較を図 16,17 亿示す. 図 16 より, 計算值，実験值とも，燃料流量增加に伴い，中心軸上温 度も增加して抢り，火炉後流の一部を除くと比較的良い 一致を示している. また図 17 より, 計算值, 実験值と あ燃料流量の増加に伴って受熱量が増加し，そのピーク が前壁から 0.8〜 $1.0 \mathrm{~m}$ の距離にあることなど，比較的良 い一致を示している.
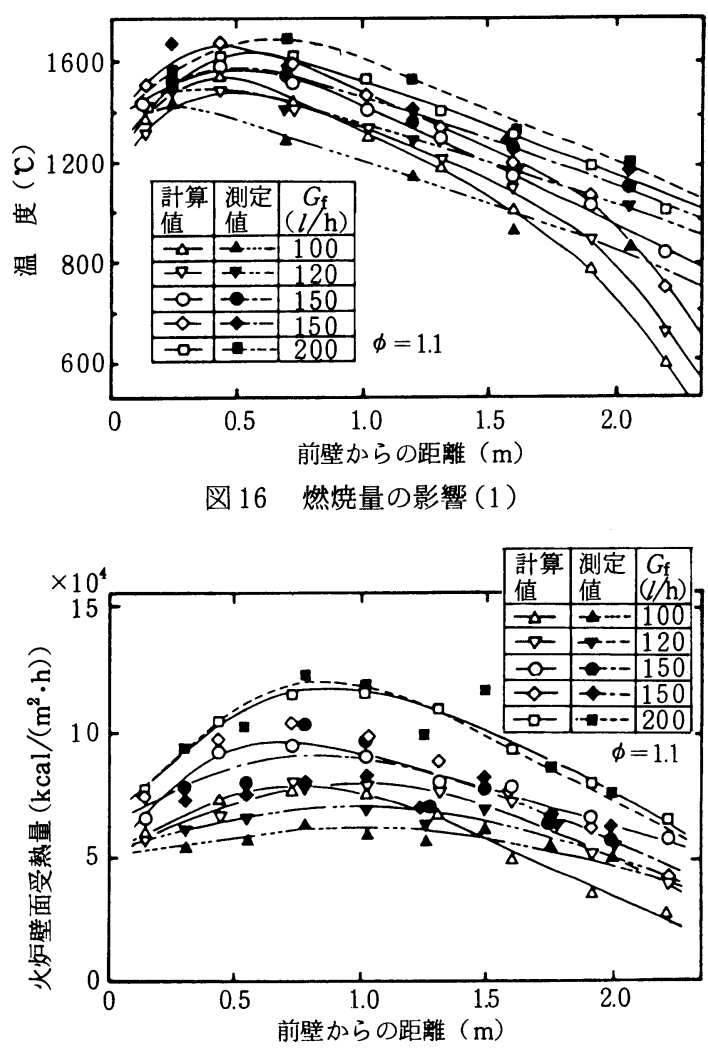

図 17 燃焼量の影響 (2)

4.3.4 解析精度 中心軸上温度分布計算結果と, 測定結果の比を求め, 全実験ケースについて図 18 亿示 す. 横軸は火炎長さで無次元化したノズルからの距離を 表わしているが，乙れが 1.0 以下，すなわち火炎中の方 が解析精度が良いととが分かる. しかし火炎外の領域で も $\pm 10 \%$ 程度の範囲に納まって抢り，全体として十分実 用になると考えられる.

以上の結果より， 3 次元粘性流れによる流動解析・内

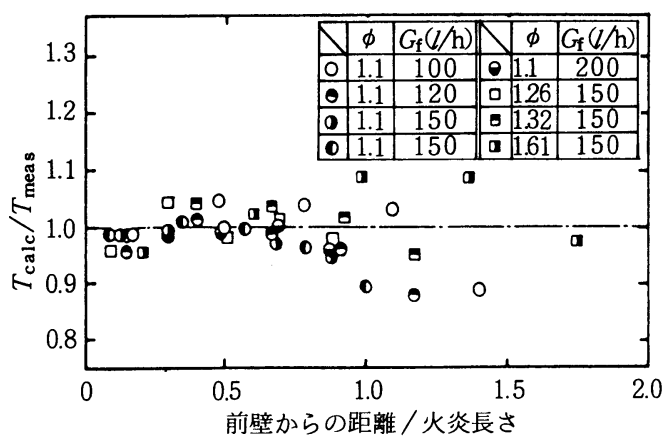

図 18 火炉中心温度の測定值之計算值の比

部にWiebe の燃え切り関数で与えられる発熱量分布を有 し，加実際に近い形状を有する火炎を組み込んだ然焼 モデルと，放射及び対流伝熱及び流れによる熱移動の解 析との組み合せによる火炉内の伝熱解析手法は，実際の 火炬に十分適用可能であるととが示された。

今後, 他の火炉に抢ける実験結果との比較を進め, そ の適用範囲の検討を進めることとしたい.

\section{5. 結 び}

（1） 3 次元火炉内の流動, 燃焼, 伝熱を, 各現象のモ デル化も含めて同時に考慮し, 火炬内温度分布之火炉壁 面受熱量分布を求める手法をまとめた.

（2）火炉内の流動様式として，一様流れ，2 次元ポテ ンシャル流れ， 3 次元粘性流れを取り上げ，火炬内伝熱 に及ぼす影響を調べた結果, 発熱量分布の影響に比し, 流動様式の差の影響は少ないてとを明らかにした。

（3）火炉内の燃焼モデルとして，Wiebe の燃え切り関 数による発熱量分布を有する火炎モデルを用い, 計算値 之実験值の比較より, 実験時の発熱量分布を推定する手 法をまとめた.

（4）燃焼条件と発熱量分布の関係を調べ，乙れを用い て各条件に対し，炉内温度と壁面受熱量の分布を算出し た結果，実験值と実用上十分な精度で一致することを確 認した.

本研究費の一部は, 昭和 55 年度科学研究費一般研究 （C）「火炬内の燃焼，伝熱シミュレーションに関する研 究」によるものである. また数值計算に当っては，北海 道大学大形計算機センターを利用させていただいた．こ こに深く謝意を表わす次第である.

\section{文献}

1）石谷，機械学会論文集，第 23 巻，136 号，929 頁(昭 32)

2）山崎，機械学会論文集，第 25 巻，156 号， 777 頁(昭 34)

3) H. C. Hottel, E. S. Cohen, A.I.Ch.E.J., Vol. 4, No. 1, pp. 3, (1958)

4) A. D. Gosman, et al., Heat and Mass Transfer in Recirculating Flows, pp. 207 (1969), Academic Press

5) 谷口, 舟津, 機械学会論文集, 第 36 巻, 284 号, 610 頁 (昭 45) 
6) 谷口, 杉山, 谷口, 機械学会論文集, 第 39 巻, 324 号, 2473 頁 (昭 48)

7）パトリック・ローチェ,コンピュータによる流体力学(上), 304 頁(昭 53), 構造計画研究所

8）シトケイ，ディーゼル機関内の燃料噴射と燃焼，169頁 （昭 $41 ）$, 朝倉書店

\section{〔質疑応 答〕}

\section{質問者 大阪産業大学 石谷清幹}

〔澌問〕火炉内 flow patternは燃焼方式により大差が あることは中井 (日立造船)，Salamと加治(阪大)らの研 究結果もこれを裹付けている. そこで,

(1) flow patternの差異は貴解法ではどのような方 法でどこにより入れることになるのか.

(2) ASME Furnace Performance Committeeが行 った 4 種のボイラ (Tidd Station, Paddy's Bay Station, Willow Island Station 等)に対する実験的研究結果を貴 方法によって解析しなおす作業を実行されたか. あしま だならば，信用できる実験データがそしいBoiler Furnace 内のHeat Transfer 研究の実状にかんがみ，実行 されてその結果得られた知見をご教示願いたい.

〔回答〕（1）本解析手法に扔いては，フローパターン の差異を火炉内のエンタルピ流れと火炎の発熱量分布と に組み入れている．前者については，本論文と同様の流 動解析手法により三次元粘性流れを解き，質量速度分布 を求め, 本論文中の式 (8) により計算すればよい. また, 後者の発熱量分布については, 本解法ではWiebeの燃え 切り関数を使用した.ただし，乙の発熱量分布について は, フローパターンで変化すると考えられるが, 現在の ところ，本論文で扱った単一バーナの小形直方体ボィラ 火炉についてしか，その分布が明らかでない，したがっ て，今後，で質問中で示された各種ボイラの実測値を用 い, Wiebe関数の係数推定法を確立していく考えである. さらに，あっと基礎的な流動之燃焼の関連を検討する実 験室規模の研究も並行して行い, 発熱量分布の定式化を 目指して行くつもりである. ただし，乙れらの方法は， 実用という観点から, 複雑で不明確な燃焼現象を考慮せ ずよむよいWiebe の関数などによる定式化が望ましく， 工業的にあ簡便で実際的であると考えている.

（2）著者らの開発した解析手法の目的とするところは, 火炉内の温度分布・火炬壁面の受熱量分布を求め, 火炬 の高負荷化や低公害化に対処できる予測手法を確立する ことである. このため，本研究に関連して進めている，

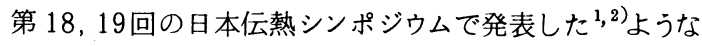
火炉形状の影響を考慮した解析手法により，現在，175 MW火力発電所用ボイラでの実験結果との対応を行って 抢り(日本機械学会北海道支部第 24 回講演会で発表の予 定），その結果を見てで教示頂いたASMEのボイラ火炉 やその他の各種火炉の実験結果に対しても鋭意, 解析を
進めていきたいと考えます.

\section{文献}

1) 早坂ほか, 第 18 回日本伝熱シンポジゥム(昭 56-6), 118 .

2) 早坂ほか, 第 19 回日本伝熱シンポジウム(昭 57-5), 286. 質問者 船舶技術研究所 玉木恕乎

〔罂問〕非常に複雑なボイラ火炬内の伝熱現象の解明 に取組まれていることに敬意を表します，以下の点につ き質問します.

（1）本シミュレーションでは流動と伝熱のモデルにつ いて物理的に説明のつく厳密な検討を行っているが, 結 果に影響の大きい発熱量分布を求める燃焼モデルに (7) 式のWiebe による実験式を使って抢られる，乙の燃焼モ デルに, ガス温度とガスの濃度の関数で表わされる燃焼 反応式(アレニウス式)を使用される打考えはないか.

（2）実験で発熱量分布を変えるために，例として残留 炭素分が異なる燃料を使用してはどうか. Wiebe の実験 式で与える定数 $m$ 亡 $t_{l}$ が燃料の特性によって変わるので はないか.

【回答〕（1）現在, 小形円筒実験炬での実験結果のシ ミュレーションで検討する予定である. ただし，ガス燃 料の燃焼反応に対してさえ, その適用にはかなりの仮定 が必要であり，本論文のように重油の噴霧燃焼の場合は， さらに難しいと考える.

（2）で指摘のように，残留炭素分などによる燃料特性 の違いで, 発熱量分布は変化すると考えられますが, 火 炉入口のバーナ側で大きな発熱を示し，その後徐々に低 下するという基本的な傾向は変らないものと考えます. この燃料特性が発熱量分布へ与える影響の検討は, 本論 文で使用したボイラが廃棄されたため, 今後, 小形円筒 実験炉で行っていく予定である.

質問者 三重大学工学部 藤本 元

〔質問〕精力的なご研究に敬意を表します。下記につ きご教示下さい.

（1）燃焼ガス定圧比熱一定の場合之温度の関数(例え ばJANAFあるいはEdsonのデータ)とした場合では， 発熱量によ゙の程度の差が出るのでしょうか. なおディー ゼル機関では後者を用いて計算することが多い様です.

（2）Wiebe 関数の指数 $m$ は，実験值之計測値を合わせ るための操作項の様に思われます．貴論文の炉の場合は ガスタービン燃焼器に近いと思われますが, 参考文献 8) では $m>4.0$ とあり，貴論文の $m<1.0$ はディーゼル機関 に相当しています．乙の原因についてはどのようにお考 えでしょうか.な拉，定常燃焼と非定常燃焼の差はあり ますが，貴論文の仮定 (1)を同様に採用してディーゼル 機関の熱発生予測をした池上ら，神本らの考え方を用い るほうが発熱量予測の観点では良いように思われます。

（3）上記に関連しますが, 燃焼時間 $t_{z}$ の決め方をお示 し下さい. 乙の場合は噴射弁を出た燃料が火炎ゾーン内 を通過して燃え切るまでの時間ということでしょうか. 
〔回答〕（1）ディーゼル機関に㧊いて，通常現われる 温度範囲が 800-2000 K程度であるのに対して, ボイラ 火炉では，その範囲が狭く本論文では，発熱量分布が問 題となる領域でみると $1200-1550 \mathrm{~K} て ゙ あ り ，$ 燃焼ガス 比熱を温度の関数としてあ発熱量分布に大差はない. こ の点の確認のため, 燃焼ガスの定圧比熱を温度の関数と し，再計算したところ火炉中心軸上の温度には，平均で 4 度, 最大で 12 度の差が出たが, 乙の程度では発熱量 分布の個々の值に対して，1.0\%以下の補正量であった.

（2）ボイラ火炉内の燃焼が内燃機関と比べると定常燃 焼であること、またガスタービン燃焼器と比べても低圧 力，低燃焼室負荷下の燃焼であるととなどを考慮すると， ボィラ火炉内の発熱量分布は, 単純に前二者の特性の延 長としては考えるべきではない，さらに，ボイラ火炉で は, ガスタービン燃焼器と比べると, 入熱量の $50 \%$ 以上 が、主として放射熱伝達により火炉水冷壁に吸収される ため，燃焼は比較的低温下で緩慢に行われている．以上 のような燃焼条件の違いにより，本論文で示すような発 熱量になったものと考えている.

また, 池上, 神本らの熱発生予測の考え方は, 非定常 燃焼の場合のあのであり，着火遅れなどが直接問題とな らない本論文には，そのまま用いるととはできないと考 えている.

（3）燃焼時間 $t_{z}$ は，火炉内中心軸上質量速度分布加ら 火炎ゾーン(本論文図 2 参照)を通過する時間として求めた. 質問者 川崎重工(株)大阪工場 伊藤征矢

〔㸞間〕（1）ボイラの設計に抢ける従来の燃焼室の熱 計算は, 燃焼室と後部対流伝熱面 (燃焼室出口以降の伝 面)との熱バランスを求めることが主目的であったので, 1 点近似法が用いられていた. しかし, 実缶での実測に よると燃焼室炉壁での吸収熱量は場所的に差異があるて とが確認されており，その点で本研究は有用であると思 われる(特に水循環計算をする上で).

本研究に打いて，ボイラ後部伝熱面の熱計算に用いる 燃瑨室出口ガス温度はどの部分をとればいいか。そして， その温度を用いて後部伝熱面の熱計算をした結果は実測 值と一致しているか.

（2）図13の表わす物理的意味を空気過剩率と（7）式 との関連に扔いてで説明願いたい.

（3）本研究に用いられたボイラは蒸発量 $2 t / h$ と小さく, またバーナが一本である. 本解析法を、複数バーナの大形 ボイラに適用するときのモデル化の手法を打伺いしたい．

【回答〕（1）本論文は，熱の移動が主として放射によ り行われているボイラなどの火炉の放射伝熱部に注目し て解析したもので，後部対流伝熱面に対する伝熱計算は 現在のところ検討していない，しかし，本解析では，付 図 1 のように後部対流伝熱面へ流入するガスの温度分布 が得られ，より厳密な後部対流伝熱面での伝熱計算が可 能となるものと思われる.

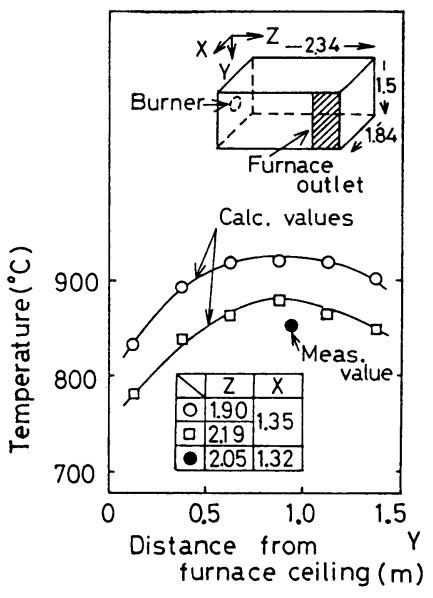

付図 1 火炬出口部の温度分布

（2）式(7)における $t_{l}$ の持つ意味は， $m$ を一定として $t_{l}$ を変化させた場合の発熱量分布の傾向 (四 3 参照) から 分かる.つまり, $t_{l}$ の大きいほどバーナ近傍での発熱量 の割合が大きくなる．とのととより， $t_{l}$ は燃焼速度を表 わす一つの指数といえる.

図 13 亿戻って， $t_{l}$ の值の変化を見てみる之， $t_{l}$ の大 きい，つまり燃焼速度の速い場合は，空気過剩係数 $(\phi)$ が一定なら燃焼量 $\left(G_{f}\right)$ の大きい条件か， $G_{\mathrm{f}}$ が一定なら $\phi$ の小さ条件の時である. 乙の両条件下では, 火炎寸 法が大きくなって损り，火炎中心部の温度が上昇し(図 14 ， 16 参照)，燃焼速度が速くなる場合に相当していることが 分かる．また， $t_{l} に$ 上限值が生じるのは，火炉内に火炎 が充満し，火炎中心部の温度上昇がなくなり，燃烓速度 が速くならないためであり，火炉の最大負荷の状態である.

（3）本論文に関連して, 発電所用ボイラを対象とした 研究も行っている ${ }^{1)}$. その研究においては，火炉底面木 ッパやデフレクションアーチなどの火炉形状の影響を検 討するとともに，火炉内流動は， R.A.Swayerが用いた 自由喷流の計算式 ${ }^{2,3)}$ を使って二次元粘性流として解い ている.しかし，一般に複数バーナの大形ボイラでは， 火炉内において各バーナからの噴流が相互に干涉する複 雑なあのと思われ，モデル化が困難である．けれども， 発電所用ボイラ火炉のように火炉寸法が，バーナ部付近 の複雑な流れの領域の寸法よりかなり大きい場合に，著 者らは, 複数バーナ部を一つの大きな開口部と考え, 前 述の噴流としての取扱いによりモデル化を行っている. こ の結果については，第 19 回日本伝熱シンポジゥム(昭和 57 年 5 月・名古屋)において発表予定である.

\section{文献}

1) 早坂ほか, 第18回日本伝熱シンポジゥム(昭56-6), 118.

2) Sawyer, R. A., J. Fluid Mech., 17-4 (1963-2), 481.

3）広瀬ほ力, 機論, 36-292(昭 45-12), 2093. 